\title{
THE NINTH INTERNATIONAL SYMPOSIUM ON SALT AND THE ECOLOGICAL IMPORTANCE OF SOLAR SALTWORKS
}

\section{N.A. KOROVESSIS}

Received: $15 / 09 / 09$

Accepted: 20/10/09
Hellenic Saltworks S.A.

Asklipiou 1 str., 10679 Athens, Greece

*to whom all correspondence should be addressed: e-mail: nkor@hol.gr

\begin{abstract}
The Ninth International Symposium on Salt (www.worldsalt2009.com) organized by China National Salt Industry Corporation, China Salt Association and many other salt organizations of the world was held in the Beijing International Convention Center on the 4-7 September 2009. It is the ninth in a series of symposia since 1962 when the first meeting held in Cleveland, USA. The World Symposia on Salt specialize in reporting and discussing progress of the latest development and views of salt industry world wide. They cover the whole spectrum of subjects dealing with the science, engineering, technology, economics and history of all type of salts and other evaporites.

One hundred eighty five (185) papers were presented in six parallel sessions grouped into the following topics:

1. Vacuum Salt Production and Reduction of Energy Consumption in Salt Production

2. Rock Salt Production and Utilization

3. Sea/Lake Salt and Biology

4. Salt Chemical Production

5. Salt Culture, History and Education

6. Salt and Health

7. Salt Processing and Quality Assurance

8. lodized Salt for IDD Elimination

9. Salt Marketing
\end{abstract}

More than twenty presentations were related to biological process of Solar Saltworks and their Ecological Importance, among 75 presentations that were dedicated to Solar Saltworks. The present work focuses on the presentations and also the discussions that took place in Beijing Salt Symposium that are mainly related to the topics of the $1^{\text {st }}$ and $2^{\text {nd }}$ International Conferences on the Ecological Importance of Solar Saltworks $\left(1^{\text {st }}\right.$ and $2^{\text {nd }}$ CEISSA, www.alasecology.org, www.gnest.org) held in Santorini, Greece, 2006 and Merida, Mexico, 2009 respectively.

KEYWORDS: Solar saltworks, Salinas, Biological process, Production process, Artemia, Dunaliella, Biological management, Ecosystem, Wetlands.

\section{SOLAR SALTWORKS' BIOLOGICAL PROCESS}

The study of microbial processes in saline waters such as saline lakes, coastal wetlands and solar saltworks is a very active area of research worldwide. An extremely important component of Salinas and hypersaline systems is the microbial community. Not only are microbes able to withstand salt stress, but they serve several functions in the hypersaline environment (Litchfield, 2009). The highly diverse biological system of solar salterns, with evaporation ponds and crystallizer ponds of different salinities, with often high densities of phototrophic microorganisms, planktonic as well as benthic, makes the salterns excellent model systems for the study of primary production and other microbial processes (Oren, 2009b). 
We particularly emphasize on solar saltworks because they are a unique case of manmade wetlands that are specially designed to produce a commodity, using as raw material the practically inexhaustible seawater and mainly renewable energy (Davis, 2009b). They are most efficient converters of solar energy into an inorganic commodity. Conversion rate of solar radiation into removal of water vapor from the brine takes place with $45 \%$ efficiency (Sedivy, 2009a). Their uniqueness is based in the fact of coexistence of regular and hypersaline waters in their pond system where an important biological system is developed and establishes high significant shelters for wild life.

Solar Saltworks (marais, salants, salterns, saltfields, salinas, solinzi) use renewable energy from wind and sun to evaporate seawater, inland brines or subterranean saline water in outdoor ponds and manufacture salt (sodium chloride) (Davis, 2009c). They are specially designed according to their area characteristics and the prevailing weather conditions. They consist of a system of shallow ponds (15-60 cm deep), connected mainly in series which are divided into two basic groups. The first group, usually called evaporation ponds, is used to concentrate seawater up to saturation, with respect to $\mathrm{NaCl}$, salinity $\left(25.7^{\circ} \mathrm{Be}\right)$ and covers $90 \%$ of the production area. The second group, called crystallizers or pans, consists of the ponds where salt crystallizes via further evaporation of the brine up to $28-29^{\circ} \mathrm{Be}$. Crystallizers take up the remaining $10 \%$ of the production area.

The salinity vector that develops throughout the pond system with a simultaneous and continuous reduction of brine volume constitutes the physical process of solar saltworks. It is a steady state process (Korovessis and Lekkas, 2009) since optimal operation results in retaining constant conditions in terms of brine salinity and depth in every pond. This is a major advantage to all natural wetlands which are transient processes.

The biological process of solar saltworks develops in parallel with the physical process and constitutes of a planktonic community (organisms suspended in the brine) and a benthic community (organisms living on pond floors). The steady state physical process of solar saltworks, aids in developing and maintaining maximum species diversity of planktonic communities in each salinity range (pond), which power and control the living organisms at desired levels and increase brine evaporation rate. Furthermore it aids in developing and maintaining mats firmly attached to pond floors that sustain desired thickness, preserve biodiversity, remove and permanently sequester nutrients from the overlaying water and control leakage and infiltration (Davis, 2000).

Obviously the biological process affects the physical process and vice versa. If an unfavourable community of microorganisms finally develops in the concentrating ponds we end up with viscous and turbid brines in the crystallizers. It is generally accepted that viscous brines cause sodium chloride to crystallize in low quality crystals as agglomerates with increased entrapped brine. Sometimes the produced salt bed is very loose and therefore very difficult to harvest.

However the exact mechanism that viscous brines affect sodium chloride crystallization process is not known. Although it has been widely recognised in the salt community that healthy biological systems in solar saltworks lead to higher salt production and better salt quality, however a comprehensive explanation of the biological, chemical, and physical mechanisms that cause sodium chloride to crystallise as monocrystals from 'healthy' brine or as agglomerates from viscous brines, has yet been developed (Sedivy, 2009b). Mr. Sedivy speculated about the nature of the "missing link" challenging the scientific community to search for the compound(s) that may be critical in solar salt production. Following his presentation and the discussions that took place during the works of the $2^{\text {nd }}$ International Conference on the Ecological Importance of Solar Saltworks $\left(2^{\text {nd }}\right.$ CEISSA), the first contribution in that effort offered by Professor A. Oren's presentation in the $9^{\text {th }}$ International Symposium on Salt (Oren, 2009a). More scientific research is expected in the near future aiming in the quantitative determination of the "missing link".

\section{KEY MICROORGANISMS}

Key organisms, common in the biological process of most solar saltworks are Aphanothece halophytica, Dunaliella salina, Artemia salina and the Archaea (herein designated the red 
halophilic bacteria). Their presence or absence, colors and concentrations and performance under favourable or adverse conditions are highly important to salt production and the quality of the product (Davis, 2009a).

A number of presentations have been dedicated to the role of halophilic bacteria in salt crystallisation (Rahaman et al., 2009); Dunaliella salina, an energy conversion microalgae (Reginald et al., 2009; Henfy et al., 2009); the current research trends and application of artemia (Xin, 2009); the species composition and distribution of phytoplankton and zooplankton in Tanggu solar saltworks (He et al., 2009); the biological role of sodium ions (Matsuda et al., 2009) and the effect of $\mathrm{Na} / \mathrm{Mg}$ ratio in artificial and natural seawater on the hatchability of artemia cysts (Zhang, 2009).

The green microalgae genus Dunaliella was chosen for a presentation that focus to problems focus to the acquisition and metabolism of organic nutrients and on the consequences of exposure to high light and UV radiation (Giordano et al., 2009).

Mass cultivation techniques for commercial application also reported for Dunaliella salina (Jun-jie Zhang et al., 2009) and Artemia (Xin, 2009).

\section{MANAGEMENT OF SOLAR SALTWORKS PRODUCTION PROCESS}

Solar Saltworks particularly modern operations need to optimize their production process in order to meet their goal that is to produce high quality sodium chloride according to market demands.

Leaders and technicians of solar salt industry have realized that they operate coastal ecosystems rather than common industries. Management of the physical system is not sufficient to produce high quality sodium chloride. Thus optimization of solar saltworks production process requires management of the two interlocked systems the physical and the biological (Davis, 2006).

Considering both processes we can say that they are affected mainly from the following:

- Quality of the intake seawater

- Production area design

- Solar saltworks operation

It is worth to mention that solar saltworks develop a favourable to salt production or 'healthy' biological process if they are fed directly from open seas with pure seawater and if care has been taken for their proper design and operation. The quality of the intake seawater is very crucial for the characteristics of the biological system that develops in solar saltworks. Most of the encountered problems are connected with the case of operations that are fed from lagoons, bay waters and subterranean brines or sometimes even from open seas where the intake seawater is enriched by nutrients coming from human activity.

Usually the disturbances in concentrating ponds' biological process develop slowly and they are often unheeded until severe effects attract attention (Davis, 2009a).

Management of mild disturbances can be achieved by just monitoring and proper rearrangement of the operation procedure considering that the production area has been properly design.

In the case of severe disturbances one has to intervene in the chain of microorganisms that develop in the pond system in order to control the process. Artemia inoculation is the usual method that has been applied to maintain maximum species diversity in solar saltworks ponds and retain a 'healthy' biological process. ISYSA, Yucatan, Mexico, produces and inoculates great amounts of brine shrimp continuously in the evaporation ponds where the physical conditions (salinity and temperature) are optimal for the good development and reproduction. The work focused in the design of a continuous culture and great production of brine shrimp in suitable facilities to make adequately these works, as well as the culture of great concentrations of the microalgae Dunaliella viridis like live food for the cultures of brine shrimp (Ortiz, 2009b).

The bio-management of artemia is also reported. A technique that combines the concentrated multiplication with culturing of artemia during the whole production process (Zhiling, 2009). 
Artemia and Dunaliella viridis inoculation in solar saltworks is also proposed, where the intake seawater is received from nearby desalination plant (Sun et al., 2009).

If the intake seawater has increasing concentrations of nutrients in the form of combined nitrogen, phosphate and organics coming from human activities the a.m. management techniques may not be sufficient. Cooperation with local authorities is very essential in order to control intake seawater loading with nutrients and organics.

Analytical presentations have been dedicated to the management of the biological systems of continuously operated solar saltworks (Davis, 2009a), seasonal solar saltworks (Davis, 2000) and also an overview of the function and management of the solar saltworks biological system (Davis, 2009c).

A number of presentations have been dedicated to the behavior of microorganisms developed in solar saltworks and applied methods of management (Ortiz, 2009b; Venkat, 2009).

The salinity impact on the microbial diversity in solar saltworks is reported (Litchfield et al., 2009a and Furtado et al., 2009).

The structure of phytoplankton and macrobenthic invertebrates communities in the low salinity ponds of a productive saltworks as well as the major abiotic determinants of the observed biotic patterns were presented (Evagelopoulos et al., 2009).

Finally a technique reported to determine the metabolic production and reduction of oxygen by benthic community in solar saltworks (Coleman, 2009).

\section{SOLAR SALTWORKS ECOLOGY}

The biological process that develops in the evaporation pond (shallow lake) system transforms actually Solar Saltworks into integrated coastal wetlands and as they are steady state processes, unlike natural wetlands which are all transient processes, they develop better ecosystems functioning through the whole year (Korovessis and Lekkas, 2009). It has been reported in $2^{\text {nd }}$ International Conference on the Ecological Importance of Solar Saltworks ( $2^{\text {nd }}$ CEISSA, Mexico 2009) that if solar saltworks are destroyed we will lose a significant source of microbial diversity (Litchfield et al., 2009b).

Basic organisms of solar saltworks biological system constitute excellent food for a large number of birds living in the solar saltworks for that reason. Certain species of birds, especially Avocet, Black-necked Grebe, Kentish Plover etc., depend directly on saltworks productivity since their diet is exclusively based on artemia salina, which is also part of the diet of the beautiful flamingos and it colours orange their feathers. More than 100 species of birds have been observed in every solar saltworks in Greece (188 in Kitros Saltworks in 1990). Many of them are protected by Greek, European or International conventions. (Korovessis et al., 2009).

Fifty species of birds are observed in the salt ponds of Industria Salinera de Yucatan S.A. (ISYSA) of which 29 are of aquatic habits and 21 terrestrial. Caribbean flamingos are the most abundant birds finding the major concentrations (5,500 individuals) in the low salinity ponds because of the presence of great amount of fish larvae and in high salinity ponds where artemia is present (Tabasco Contreras et al., 2009).

Solar saltworks are almost always part of larger coastal ecosystems protected by the International Ramsar Convention. In many cases they are included in National Parks and in Europe they are all concerned by the Natura 2000 network.

The SALINS Group welcomed Natura 2000 and actively lobbied to be included in the network. An ecosystem manager was recruited to define and be in charge of the environmental strategy on the saltworks by the implication of the scientific partners and the SALINS staff, mainly in France which represents the major areas. An environmental management plan is implemented for each company's site (Sejourne and Matrat, 2009).

Environmental Studies associated with the operation and expansion of existing operations and new investments in solar saltworks have also been presented. Presentation on Margherita di Savoia Saltworks (Zeno, 2009); Krystalline Saltworks, Malindi, Kenya 
(Rahaman et al., 2009) and the environmental studies undertaken by Straits Resources Ltd. for the approval process of the Yannarie Solar project (Mottershead and Davidson, 2009).

Studies on sustainable development and utilization of salt lake resources referring to Qinghai Lake, China (Huai-ke et al., 2009), (Bai, 2009) and Quaroun Lake, Egypt (Dardir and Wali, 2009) and Schinias wetland, Hellas (Hadjibiros et al., 2009) were also presented.

The associations of mangroves works as barriers along with saltworks in order to reduce the propagation of polluting elements in waters of the estuary, assuring the quality and therefore the development of local salt production. A survey was undertaken for the identification of the degraded areas of mangrove swamps near the local saltworks with later implementation of methods and models for environmental recovery of those areas (Rocha et al., 2009b).

Numerous saltworks have been abandoned throughout the Greek islands and mainland as operations have decreased in number and increased in size. Such areas have great potential for serving the broader society if rehabilitated correctly. Changes in landscape uses, especially agricultural practices and rapid expansion of vacation homes and resorts in the islands, have increased nutrient and sediment loading to coastal bays. When saltworks were in operation streams of the surrounding area were diverted around saltworks on the coast to avoid contamination of the salt produced. Rehabilitation of those saltworks to accept stream input has great potential to treat nutrient and other contamination from the landscape via natural biological processes of the ecosystem, thus reduce loading to coastal areas and potential contamination of resort beaches. Successfully rehabilitated saltworks will also provide enhanced nature conservation areas that can become part of regional networks of ecotourism opportunities (Crisman et al., 2009).

A new business model presented for the preservation of solar saltworks at risk (Sovinc, 2009).

\section{ENVIRONMENTAL EDUCATION}

We have already referred to SALINS Group investment in environmental management of company's cites. Islets have been built and restored to improve nesting conditions for colonial charadriiforms (gulls, terns and avocets). Biological knowledge has been improved: more than 300 bird species, at least 300 plant species and 21 species of reptiles, amphibians and mammals have been identified by scientific partners. The SALINS Group staff participates in banding operations of chicks and monitoring of the medical and nesting birds status. Their naturalist skills are also improved by training on birds and plants. All this information has been recorded in a Geographical Information System and a Naturalist database. Access by the general public is managed in a controlled and limited way on the sites. The SALINS Group carried out panels presenting the saltworks biodiversity and it regularly takes part in environmental demonstrations like the World Wetlands Days to improve the image of the company and the reputation of their sea salt brands (Sejourne and Matrat, 2009).

Hellenic Saltworks S.A. has enrolled the EU Eco-Management and Audit Scheme (EMAS) to evaluate, report and improve company's environmental performance. An environmental management plan has been implemented for the three main saltworks of the company Messologhi, Kitros and Kalloni.

Mr. DeMendeiros Rocha (Rocha et al., 2009a) informed the salt community that Brazilian saltworks have gone one step further. They are invested in environmental education for all leaders and civil servants. The trainings realized in each saltwork presented two different methodologies, composed by expositive classes and practical exercises. Those courses are developed next to the chosen public of leaders and technicians, and also with civil servants of the salt. These courses are developed with a target audience composed of managers and technicians with complete degree and or incomplete university study, along with other employees of saline, which usually have a complete or incomplete elementary and high school.

During the exhibition in lectures, the following content are addressed:

$\checkmark$ ecology of hypersaline environments

$\checkmark$ Saltwork as ecosystems

$\checkmark$ Potential environmental problems involved in the production of salt 
$\checkmark$ Ecosystems adjacent to saltworks(mangrove, savanna steppe, flooded, etc.).

$\checkmark$ Environmental monitoring of the estuary.

In practical classes (with binocular microscopes and magnifying lenses) are exposed to various agencies that comprise the ecosystem of saline in the state Rio Grande do Norte, involving knowledge about the ecology of the environment, such as:

$\checkmark$ Planktonic Community (phytoplankton and zooplankton)

$\checkmark$ Water filtration process carried out by microcrustaceans Artemia spp.(Crustacea: Branchiopoda: Anostraca)

$\checkmark$ Artemia spp cyst occurrence and form.

$\checkmark$ Analysis of different sodium $\mathrm{NaCl}$ crystals produced in saline.

Practically, about 3.000 employees and managers already experienced this kind of course, receiving theoretical-practical guidelines on hypersaline environments and associated ecosystems (mangrove, for example).

Following that program the legal requirements of actions in this new axis of surveillance and environmental control of companies, environmental education courses in hyper saline environments began to appear on the pre-requisite list of the state environmental agency (IDEMA) to issue the license to operate any company for salt production.

It is also worth mentioning the fact that during and after the training, the environmental issue is now considered necessary for the success of the company. These results suggest the need for expansion of activities in environmental education in solar saltworks worldwide (Rocha et al., 2009a).

\section{CONCLUSIONS}

The $9^{\text {th }}$ International Symposium on Salt demonstrated that the study of microbial processes in saline waters such as saline lakes, coastal wetlands and solar saltworks is a very active area of research worldwide. Especially the participants of the $1^{\text {st }}$ and $2^{\text {nd }}$ CEISSA had a very strong presence and contributed for the success of Beijing symposium. Concerning solar saltworks the undergoing scientific research aims at the following goals:

- Optimization of the produced solar salt quality through adequate management of the two interlocked biological and physical processes

- Optimization of the ecology and generally the wetland function of solar saltworks

- Promote all connected with solar salt production actions, such as environmental education, salt museums, ecotourism and saline water - mud baths

Solar Saltworks in parallel with their main objective that is to produce salt, they additionally function as wetlands and contribute to the conservation of the environment, which is highly valued in our times. They offer their share in safeguarding globally the remaining wetland areas just as citizens in a well functioning democracy should offer their share in common interest. Solar saltworks should be officially indentified as constructed wetlands and should be included in the list of protected coastal ecosystems.

\section{REFERENCES}

Bai F. (2009) Improve the Utilization of Salt Lake Resource with the Principle of Recycle Economy, In: Proceedings of the $9^{\text {th }}$ International Symposium on Salt, Sha Zuoliang (Ed.), Gold Wall Press, Beijing, Vol. A, 787-790.

Coleman M.J. (2009) Carbon Sequestration in Benthic Mats of Solar Ponds, In: Proceedings of the $9^{\text {th }}$ International Symposium on Salt, Sha Zuoliang (Ed.), Gold Wall Press, Beijing, Vol. A, 765775.

Crisman T.L., Takavakoglou V., Alexadridis T. and Zalidis G. (2009) Rehabilitation of Abandoned Saltworks to Maximize Conservation, Ecotourism and Water Treatment Potential. Global NEST Journal, 11(1), 24-31.

Dardir A.A. and Wali A.M.A. (2009) Extraction of Salts from Lake Quaroun, Egypt: Environmental and Economic Impacts, Global NEST Journal, 11(1), 106-113. 
Davis J.S. (2000) Structure, Function and Management of the Biological System for Seasonal Solar Saltworks, Global NEST: the Int. Journal, 2, 217-226.

Davis J.S. (2006) Biological and Physical Management Information for Commercial Solar Saltworks., In: Proceedings of the $1^{\text {st }}$ International Conference on the Ecological Importance of Solar Saltworks, Lekkas T.D., Korovessis N.A. (Eds.), GNEST, 20-22 October 2006, Santorini, Greece, pp 5-14

Davis J.S. (2009a) Management of Biological Systems for Continously - Operated Solar Saltworks, Global NEST Journal, 11(1), 73-78.

Davis J.S. (2009b) Solar Saltworks: Salt Manufacture from an Environmentally Friendly Industry, In: Proceedings of the $2^{\text {nd }}$ International Conference on the Ecological Importance of Solar Saltworks, Lekkas T.D. and Korovessis N.A. (Eds.), 23-26 March 2009, Merida, Mexico, GNEST, 3-17.

Davis J.S. (2009c) Let Microorganisms Help not Harm the Salt Manufacture, In: Proceedings of the $9^{\text {th }}$ International Symposium on Salt, Sha Zuoliang (Ed.), Gold Wall Press, Beijing, Vol. A, 725-728.

Evagelopoulos A., Spyrakos E. and Koutsoumbas D. (2009) Phytoplankton and Macrofauna in the Low Salinity Ponds of a Productive Solar Saltworks: Spatial Variability of Community Structure and its Major Abiotic Determinants, Global NEST Journal, 11(1), 64-72.

Furtado I. and Fernades C.F.E. (2009) Traditional salt Production in Goa India, Enriches Diverse Microbial Resource, In: Proceedings of the $9^{\text {th }}$ International Symposium on Salt, Sha Zuoliang (Ed.), Gold Wall Press, Beijing, Vol. A, 781-786.

Giordano M. and Beardall J. (2009) Impact of Environmental Conditions on Photosynthesis, Growth and Carbon Allocation Strategies of Hypersaline Species of Dunaliella. Global NEST Journal, 11(1), 79-85.

Hadjibiros K. and Sifakaki P., (2009). Schinias Wetland: A National Park or a Solar saltwork? Global NEST Journal, 11(1), 32-40.

Henfy M.M., Dardir A.A. and Abdel-Tawab A. (2009). Effect of Dunaliella Salina on the Corossion Behavior of Technical Titanium in Saline Solutions. In: Proceedings of the $9^{\text {th }}$ International Symposium on Salt, Sha Zuoliang (Ed.), Gold Wall Press, Beijing, Vol. B, 928-936.

He H., Wang H-k., Sun Z-n., Zhang B., Zhang F. and Zhang Q-t. (2009) Investigation on Saltern Plankton in Tanggu Saltworks, Tianjin, China, In: Proceedings of the $9^{\text {th }}$ International Symposium on Salt, Sha Zuoliang (Ed.), Gold Wall Press, Beijing, Vol. A, 756-764.

Huai-ke W. and Guan-qiang J. (2009) The Utilization and Environmental Protection of Qinghai Salt Lake Resource, In: Proceedings of the $9^{\text {th }}$ International Symposium on Salt, Sha Zuoliang (Ed.), Gold Wall Press, Beijing, Vol. B, 913-916.

Zhang J-j., Guo L-c., Cui Z-q. and Sui L-y. (2009) Mass Cultivation Techniques and Commercial Application of Microalgae Dunaliella, In: Proceedings of the $9^{\text {th }}$ International Symposium on Salt, Sha Zuoliang (Ed.), Gold Wall Press, Beijing, Vol. A, 729-735.

Korovessis N.A. and Lekkas T.D. (2009) Solar Saltworks' Wetland Function, In: Proceedings of the $9^{\text {th }}$ International Symposium on Salt, Sha Zuoliang (Ed.), Gold Wall Press, Beijing, Vol. B, 887899.

Litchfield C.D., Oren A., Irby A., Sikaroodi M. and Gillevet P.M. (2009a) Temporal and Salinity Impacts on the Microbial Diversity at the Eilat, Israel, Solar Salt Plant, Global NEST Journal, 11(1), 86-90.

Litchfield C.D., Buckham C. and Dalmet S. (2009b) Microbial Diversity in Hypersaline Environments, In: Proceedings of the $2^{\text {nd }}$ International Conference on the Ecological Importance of Solar Saltworks, Lekkas T.D. and Korovessis N.A. (Eds.), 23-26 March 2009, Merida, Mexico, GNEST, pp 10-17.

Matsuda Y., Tanaka Y. and Kauda T. (2009) Biological Roles of Sodium Ions, Requisite for the Primary Production in the Marine Environment, In: Proceedings of the $9^{\text {th }}$ International Symposium on Salt, Sha Zuoliang (Ed.), Gold Wall Press, Beijing, Vol. B, 849-859.

Mottershead R. and Davidson P. (2009) The Yannarie Solar project: Design of a Solar Saltfield in Western Australia to Safeguard the Natural Environment, Global NEST Journal, 11(1), 10-18.

Oren A. (2009a) The Microbiology of Saltern Crystallizer Ponds and Salt Quality - A search for the "missing link", In: Proceedings of the $9^{\text {th }}$ International Symposium on Salt, Sha Zuoliang (Ed.), Gold Wall Press, Beijing, Vol. B, 904-912. 
Oren A. (2009b) Saltern Evaporation Ponds as Model Systems for the Study of Microbial Processes under Hypersaline Conditions - An Interdisciplinary Study of the Salterns of Eilat, Israel, In: Proceedings of the $2^{\text {nd }}$ International Conference on the Ecological Importance of Solar Saltworks, Lekkas T.D. and Korovessis N.A. (Eds.), 23-26 March 2009, Merida, Mexico, GNEST, pp 20-29.

Ortiz-Milan S.M. and Davis J.S. (2009a) Behavior of the Detrimental Microorganisms for the Solar Salt Production in the Presence of a Helpful Population of Brine Shrimp in the ISYSA Solar Saltworks, In: Proceedings of the $9^{\text {th }}$ International Symposium on Salt, Sha Zuoliang (Ed.), Gold Wall Press, Beijing, Vol. A, 791-796.

Ortiz-Milan S.M. (2009b) Project of Recovery the Biological Conditions of the Production System in Saltworks of Industria Salinera de Yucatan S.A. de C.V. (ISYSA) Damaged by the Hurricane Isidore in September of 2002, Global NEST Journal, 11(1), 91-95.

Rahaman A.A. and Jeyalakshi R. (2009a)The Role of Halophilic Bacteria in Salt Crystalization, In: Proceedings of the $9^{\text {th }}$ International Symposium on Salt, Sha Zuoliang (Ed.), Gold Wall Press, Beijing, Vol. A, 736-739.

Rahaman A.A., Venkat R, Patel D.K. and Patel K.K. (2009b) Environmental Impact Assessment of Crystalline Saltworks, Gongoni Malindi district, Kenya, In: Proceedings of the $9^{\text {th }}$ International Symposium on Salt, Sha Zuoliang (Ed.), Gold Wall Press, Beijing, Vol. B, 1122-1128.

Rahaman A.A. and Jeyalakshui R. (2009c) The Role of Halophilic Bacteria in Salt Crystallization, In: Proceedings of the $9^{\text {th }}$ International Symposium on Salt, Sha Zuoliang (Ed.), Gold Wall Press, Beijing, Vol. A, 736-739.

Reginald M., Helen Diana Y. and Laila Banu N.R. (2009) Dunaliella Salina, an Energy Conversion Microalgae in Solar Saltpans, In: Proceedings of the $9^{\text {th }}$ International Symposium on Salt, Sha Zuoliang (Ed.), Gold Wall Press, Beijing, Vol. B, 917-927.

Rocha R.M., Costa D.F.S., Medeiros D.H.M., Santos F.A.M. and Silva L.F. (2009a) Environmental Education as Practiacal Tool in Environmental Management of Tropical Solar Saltworks - The Brazilian Experience, In: Proceedings of the $9^{\text {th }}$ International Symposium on Salt, Sha Zuoliang (Ed.), Gold Wall Press, Beijing, Vol. B, 877-881.

Rocha R.M., Costa D.F.S. and Lucena Filho M.A. (2009b). Models of Environmental Recovery in Ecosystems of Mangroves Associated with Salt Production in Brazilian Solar Saltworks, In: Proceedings of the $2^{\text {nd }}$ International Conference on the Ecological Importance of Solar Saltworks, Lekkas T.D. and Korovessis N.A. (Eds.), 23-26 March 2009, Merida, Mexico, GNEST, pp 146-153.

Sedivy V.M. (2009a) Environmental Balance of Salt Speaks in Favour of Solar Saltworks. Global NEST Journal, 11(1), 41-48.

Sedivy V.M. (2009b) The "Missing Link" between Saltworks Biology and Solar salt Quality, In: Proceedings of the $2^{\text {nd }}$ International Conference on the Ecological Importance of Solar Saltworks, Lekkas T.D. and Korovessis N.A. (Eds.), 23-26 March 2009, Merida, Mexico, GNEST, pp 18-19.

Sejourne S. and Matrat M. (2009) Managing Mediterranean Saltworks as Protected Areas. The Case of Salins Group in Europe, In: Proceedings of the $2^{\text {nd }}$ International Conference on the Ecological Importance of Solar Saltworks, Lekkas T.D. and Korovessis N.A. (Eds.), 23-26 March 2009, Merida, Mexico, GNEST, pp 67-80.

Sovinc A., (2009). Secovlje Salina Nature Park, Slovenia - New Business Model for Preservation of Wetlands at Risk. Global NEST Journal, 11(1), 19-23.

Sun Z-n., He H., Wang X-k., Sha Z-I. and Zhang B. (2009) Study on the Ecological Restoration in the Solar Saltwork, . Proceedings $9^{\text {th }}$ International Symposium on Salt, Editor Sha Zuoliang, Gold Wall Press, Beijing, Vol. A, 712-724.

Tabasco Contreras M.J., Migoya VonBertrab R.E. and Ortiz Milan S.M. (2009) Monitoring of Aquatic and Terrestrial Birds within Explotation Zone of Industria Salinera de Yucatan S/A of C.V., In: Proceedings of the $2^{\text {nd }}$ International Conference on the Ecological Importance of Solar Saltworks, Lekkas T.D. and Korovessis N.A. (Eds.), 23-26 March 2009, Merida, Mexico, GNEST, pp 154-159.

Venkat R. (2009) Biological Management of Crystalline Saltworks Malindi district, Kenya, . Proceedings $9^{\text {th }}$ International Symposium on Salt, Editor Sha Zuoliang, Gold Wall Press, Beijing, Vol. B, 1133-1137. 
Xin N. (2009). Salt Pond Biotechnology Resources - Current Research Trends and Application of Brine Shrimp, In: Proceedings of the $9^{\text {th }}$ International Symposium on Salt, Sha Zuoliang (Ed.), Gold Wall Press, Beijing, Vol. A, 740-747.

Zeno C. (2009) The Ecological Importance of the Margherita Di Savoia Saltworks, Global NEST Journal, 11(1), 1-9.

Zhang F. (2009) Effect of $\mathrm{Na} / \mathrm{Mg}$ Ratio in artificial and Natural Seawater on the Hatchability of Artemia Cysts, In: Proceedings of the $9^{\text {th }}$ International Symposium on Salt, Sha Zuoliang (Ed.), Gold Wall Press, Beijing, Vol. A, 776-780.

Zhiling J. and Guangyu Y. (2009) The Promotion of Salt Quality Through Optimizing Brine Concentration: A New Technique "Bidirectional brine concentration", Global NEST Journal, 11(1), 58-63. 